Ekonomia - Wroclaw Economic Review 27/1 (2021)

Acta Universitatis Wratislaviensis

No 4066

https://doi.org/10.19195/2658-1310.27.1.5

Łukasz Kurowski

ORCID: 0000-0002-3306-4276

Szkoła Główna Handlowa w Warszawie

Ikurow@sgh.waw.pl

Piotr Górski

ORCID: 0000-0001-6185-8295

Szkoła Główna Handlowa w Warszawie

piotrgorski1@gmail.com

\title{
Znajomość zasad gwarantowania depozytów a skłonność do runu na banki ${ }^{*}$
}

Artykuł nadesłany: 2.06.2020; artykuł zaakceptowany: 28.08.2021

Kody klasyfikacji JEL: D14, G01, G21, I21

Keywords: financial education, bank run, guarantee scheme

\begin{abstract}
Knowledge on principles of guaranteeing deposits and tendency to bank run

The main goal of the deposit guarantee scheme is to prevent banking panic and consequently to prevent banking crises. The purpose of the article is to check whether the knowledge of depositors about the existence of a deposit guarantee scheme and about the terms of the guarantee affects the propensity to bank run. Thus, the presented study emphasizes that the effectiveness of the deposit guarantee scheme is dependent on the degree of knowledge about the principles of its functioning in society. The results of 200 CATI interviews suggest that this knowledge does not affect the decision to run on a bank, but determines the run type. People with higher knowledge about the principles of deposit guarantee are more likely to make a non-cash form of run (transfer of funds to another bank). For people with less knowledge the cash withdrawal is dominant. Due to the finite cash resources in bank branches, the cash withdrawal form can increase the scale of the run through its mediality.

* Badanie zostało sfinansowane w ramach grantu „Badania Młodych Naukowców” w Kolegium Zarządzania i Finansów SGH nr KZIF/BMN/14/18. Autorzy dziękują opiekunowi naukowemu prof. dr hab. Małgorzacie Iwanicz-Drozdowskej za konstruktywne uwagi do tekstu. Artykuł wyraża prywatne poglądy autorów i nie może być traktowany jako oficjalne stanowisko instytucji, w której są zatrudnieni.
\end{abstract}




\section{Wstęp}

Przed globalnym kryzysem finansowym rola edukacji finansowej była niedoceniana. Jednakże po 2008 roku powstało wiele opracowań naukowych wskazujących, że to właśnie niski poziom edukacji finansowej był jednym z powodów globalnego kryzysu finansowego (na przykład Klapper, Lusardi, Panos, 2012; Klapper, Lusardi, Panos, 2013, 3904-3923; Lusardi, Mitchell, 2014, 5-44). Osoby z niskim poziomem edukacji finansowej, zgodnie z badaniami, mają większą skłonność do nieoczekiwanych i irracjonalnych zachowań. Ponadto w krajach o niskiej społecznej świadomości finansowej w przypadku nieoczekiwanych szoków finansowych dochodzi do szybkiego spadku zaufania do instytucji finansowych oraz nadzo$\mathrm{ru}$, co prowadzi do dynamicznego wycofywania inwestycji z rynku finansowego (OECD, 2009). Co więcej, zdolność podmiotów do podejmowania świadomych decyzji finansowych jest cechą krytyczną dla rozwoju finansów osobistych, co przekłada się na efektywniejszą alokację zasobów finansowych i wzmacnianie stabilności systemu finansowego (Lusardi, Tufano, 2015, 332-368).

W artykule powiązano szczególny element edukacji finansowej (wiedzę o systemie gwarantowania depozytów) z nieodłączną częścią kryzysów bankowych, to jest runem na banki. Celem badania było sprawdzenie, czy wiedza o systemie gwarantowania depozytów wpływa na decyzję o wycofywaniu środków. Jeśli decyzja ta jest masowa, może to spowodować run na banki. Nadmierna dynamika akcji kredytowej, niski poziom zabezpieczeń kredytowych czy zdolność do regulowania zobowiązań mogą być zarządzane przez odpowiednie instrumenty makroostrożnościowe. Wydaje się, że zarządzanie ryzykiem runu na banki wymaga istnienia systemu gwarantowania depozytów. Jednakże samo istnienie tego systemu nie oznacza, że podmioty gospodarcze mają o nim wiedzę. Dlatego zarządzanie runem na banki powinno łączyć wprowadzanie systemu gwarancji depozytów $\mathrm{z}$ upowszechnianiem wiedzy o nim.

Poruszana tematyka jest ważna z punktu widzenia funkcjonowania sieci bezpieczeństwa finansowego i stabilności finansowej. W badaniu postawiono następującą hipotezę: skuteczność funduszu gwarancyjnego w zapobieganiu zjawisku runu na banki jest uzależniona od znajomości zasad działania tego funduszu w społeczeństwie. Wnioski z przeglądu literatury potwierdziły, że ogólnie rozumiana edukacja finansowa jest również dobrym narzędziem wspierania odporności systemu finansowego na szoki w postaci problemów z regulowaniem zobowiązań przez banki. Jeśli za definicję stabilności finansowej uznać sytuację, w której system finansowy jest odporny na szoki pojawiające się w gospodarce, to na podstawie niniejszego badania można zweryfikować twierdzenie, że edukacja o systemie gwarantowania depozytów powinna być potraktowana jako odpowiedni instrument wzmacniający odporność systemu finansowego. 
Aby zrealizować postawiony cel badawczy, na przełomie października i listopada 2018 roku przeprowadzono 200 wspomaganych komputerowo wywiadów telefonicznych (computer-assisted telephone interviewing - CATI). Próba została zróżnicowana ze względu na wiek respondenta, wykształcenie, miejsce zamieszkania oraz płeć. Na podstawie otrzymanych wyników można wskazać, że o ile wiedza o systemie gwarantowania depozytów (Deposit Guarantee Scheme - DGS) nie wpływa na decyzje klientów o rozpoczęciu runu na banki, o tyle ma ona wpływ na formę tego runu$^{2}$. Osoby z niskim poziomem wiedzy o DGS są bardziej skłonne do runu gotówkowego (całkowite wycofanie środków z systemu bankowego) niż osoby z większą wiedzą. Ze względu na skończone zasoby gotówki w oddziałach banków, gotówkowa forma wycofywania środków poprzez swoją medialność może spotęgować skalę zjawiska. Ponadto respondenci byli bardziej skłonni do wycofania środków w przypadku upadłości dużego banku niż małego, działającego lokalnie. Skłonność do runu jest również zależna od wielkości utrzymywanych w banku środków.

W trakcie globalnego kryzysu finansowego z 2008 roku pojawiły się nowe rodzaje paniki bankowej. W tym okresie w wielu krajach zamarły transakcje banków pożyczających środki innym bankom na rynku międzybankowym. Dotyczy to również rynku repo, gdzie działalność oparta na sekurytyzacji aktywów miała przed kryzysem subprime zasadnicze znaczenie dla działania amerykańskich banków inwestycyjnych oraz stanowiła uzupełnienie bankowości tradycyjnej (Gorton, Metrick, 2012). W Polsce zgodnie z danymi Komisji Nadzoru Finansowego dominuje działalność oparta na bankowości uniwersalnej, a depozyty bankowe stanowią 73,4\% pasywów sektora bankowego (stan na sierpień 2020 roku). Własne emisje oraz otrzymane kredyty stanowią 11\% pasywów banków. Dlatego też ryzyko związane z paniką bankową w Polsce dotyczy głównie tradycyjnego ujęcia runu, to jest wycofywanie środków z kas banków przez klientów.

Niniejszy artykuł został podzielony na kilka części. W pierwszej powiązano, w formie przeglądu literatury, zjawisko runu na banki z definicją kryzysów finansowych. Dalej szczegółowo opisano znaczenie edukacji finansowej dla rozwoju gospodarczego i prawidłowego funkcjonowania sieci bezpieczeństwa finansowego. W kolejnej części przedstawiono metodę badawczą i informacje o cechach próby badawczej. W czwartej, ostatniej, przeanalizowano otrzymane wyniki oraz wskazano najważniejsze wnioski dla polityki stabilności.

2 Dobrym przykładem runu na bank dokonanego pomimo wiedzy społeczeństwa na temat bankowości i zasad gwarantowania depozytów jest przypadek brytyjskiego Northern Rock — jednego z największych banków hipotecznych w Wielkiej Brytanii. W 2007 roku klienci tego banku zaczęli wycofywać środki z kont po tym jak na rynku pojawiły się informacje o złej sytuacji płynnościowej banku. W efekcie paniki w ciągu kilku dni zostało wycofanych 4,6 mld GBP depozytów (National Audit Office, 2009). 


\section{Teoretyczny aspekt badań}

W literaturze run na banki definiowany jest jako sytuacja, kiedy duża liczba deponentów, obawiając się, że ich bank nie będzie w stanie regulować zobowiązań w całości i w określonym terminie, jednocześnie próbuje wycofać zgromadzone środki (Kaufman, 1988, 151-164). Run na banki często towarzyszy kryzysom finansowym i dlatego wiele definicji kryzysów jest z nim powiązanych. Diamond i Dybvig (1983, 401-419) podkreślają, że globalnym kryzysom finansowym, które odegrały istotną rolę w historii sektora finansowego, towarzyszyły właśnie runy na banki. Z kolei Międzynarodowy Fundusz Walutowy definiuje kryzys finansowy jako sytuację, w której znaczna grupa instytucji finansowych ma zobowiązania przekraczające wartość rynkową ich aktywów. Prowadzi to do runu na te instytucje, upadłości niektórych z nich oraz interwencji rządu (Sundararajan, Balino, 1991). Z tego punktu widzenia poruszana $\mathrm{w}$ artykule tematyka stanowi cenny wkład w badania nad odpornością systemu finansowego na szoki wynikające z runu na banki.

Przedstawione $\mathrm{w}$ artykule badanie nie jest jedynym, w którym próbuje się ustalić zależność runu na banki i edukacji finansowej. Kim (2015) wskazał, że dla deponentów charakteryzujących się niską świadomością finansową sam fakt istnienia systemu gwarantowania depozytów nie jest wystarczający do ograniczenia runu. Klienci są bardziej skłonni do przenoszenia środków do innego banku niż wycofywania depozytów z systemu bankowego. W bardziej ogólnym znaczeniu Cole, Sampson i Zia (2011, 1933-1967) dostarczają dowodów, że świadomość finansowa wpływa na podejmowanie bardziej racjonalnych decyzji finansowych. Siła, z jaką dochodzi do paniki bankowej, zależy ponadto od wielkości banku mającego problemy z regulowaniem zobowiązań. Gdy deponenci mają odpowiednią wiedzę finansową, skłonność do runów na duże banki istotnie spada, co sprawia, że edukację o systemie gwarantowania depozytów można traktować jako element poprawiający stabilność finansową (Campioni, Larocca, Mirra, Panaccione, 2017).

Wiedza Polaków na tematy związane z gwarantowaniem depozy tów została przeanalizowana przez Jamrozik-Kierc (2008, 185-180) na podstawie badań opinii publicznej przeprowadzonych na zlecenie Bankowego Funduszu Gwarancyjnego. Badania te potwierdziły, że wiedza społeczeństwa o zasadach gwarancji depozytów na przestrzeni kilku lat nie uległa istotnej zmianie. Zarówno w roku 2003, jak i 2008 połowa respondentów sądziła, że nie ma instytucji, która gwarantuje odzyskanie pieniędzy klientów indywidualnych w przypadku bankructwa banku w Polsce. Zaskakująca jest również obserwacja, że zdarzają się pracownicy banku, którzy nie wiedzą, kto gwarantuje depozyty w Polsce.

Większość badań skupia się na defekcie koordynacji występującym na rynku depozytowym jako istotnym źródle niestabilności, prowadzącym do paniki bankowej, a w konsekwencji — do upadku niektórych banków. Defekt koordynacji definiowany jest w tym kontekście jako sytuacja, w której bank nie jest w stanie 
wypłacić wszystkim deponentom zgromadzonych środków, jeśli zerwą oni depozyty przed datą przewidzianą $\mathrm{w}$ umowie. Podejście, na którym opierają się badania w tym wymiarze, jest odwzorowaniem gry pomiędzy deponentami, którzy chcą zdążyć wycofać środki zanim dojedzie do upadłości banku. Semanova (2017) dowiodła, że edukacja finansowa może zmniejszyć problem koordynacji, a deponenci bardziej wykształceni podejmują decyzje o zerwaniu depozytu w momencie maksymalizującym zwrot z zainwestowanych środków. Również Campioni i inni (2017) potwierdzili, że w grupie badawczej o większym poziomie wiedzy finansowej problem koordynacji jest mniejszy.

Odwołując się szerzej do edukacji finansowej, należy podkreślić, że pełni ona ważną funkcję w rozwoju gospodarczym. Modele ekonometryczne i eksperymenty badawcze dowiodły, że im wyższy poziom edukacji finansowej, tym większa efektywność decyzji ekonomicznych. Dotyczy to przede wszystkim lepszych umiejętności przewidywania wartości aktywów (na przykład Christelis, Jappelli, Padula, 2010, 18-38), zdolności do akumulacji oszczędności (Banks, Oldfield, 2007, 143-170), lepszej dywersyfikacji posiadanych aktywów (Grinblatt, Keloharju, Linnainmaa, 2009), a także zorientowania na przyszłość, skutkującego większymi oszczędnościami na emeryturę (Meier, Sprenger, 2010, 193-210).

Na podstawie badań z 2009 roku można stwierdzić, że stan wiedzy finansowej w Polsce jest bardzo niski. Z raportu Fundacji Kronenberga przy Citi Handlowym wynika, że ponad połowa Polaków przyznaje się do bardzo małej lub małej wiedzy o finansach. Ponadto w badaniu można zauważyć, że jedynie $22 \%$ respondentów wiedziało, że fundusze inwestycyjne nie zawsze inwestują część naszych środków w akcje. Kurowski i Laskowska (2017, 15-23) zestawili wyniki badań Fundacji Kronenberga z wynikami badań Narodowego Banku Polskiego (NBP) dotyczącymi świadomości finansowej Polaków z 2015 roku. Podkreślili oni, że w obu badaniach deficyt umiejętności dotyczył podstawowych produktów bankowych, takich jak lokata czy kredyt. Należy zgodzić się z Komisją Europejską (2007), wskazującą, że edukacja finansowa jest najbardziej efektywnym sposobem wzmocnienia pozycji konsumentów. Jednak nie jest to działanie krótkoterminowe i efekty będą widoczne w perspektywie przynajmniej kilku lat po podniesieniu nakładów.

Edukacja finansowa jest ściśle powiązana z korzystaniem $\mathrm{z}$ usług finansowych. Rozwój coraz bardziej skomplikowanych produktów bankowych sprawia, że wzrost poziomu edukacji finansowej staje się niezbędnym elementem funkcjonowania w społeczeństwie (Iwanicz-Drozdowska, 2011). Wiedza ta wiąże się szczególnie ze świadomością ryzyka przypisanego do konkretnej usługi bankowej, a to z kolei determinuje przyszłe postawy w zarządzaniu finansami osobistymi i wpływa na stabilność systemu finansowego.

Brak wiedzy o istnieniu systemu gwarantowania depozytów jest czynnikiem, który może ograniczać zjawisko paniki bankowej. Oprócz wiedzy o systemie gwarancji, możemy wyróżnić kilka innych kluczowych przyczyn runów na banki. Jedną z ważniejszych przyczyn są plotki i niejasne komunikaty prasowe. Działanie 
to może być wywołane celowo lub przypadkowo (na przykład run na bank inwestycyjny Bear Stearns w USA). Kolejną przyczyną są wewnętrzne czynniki kryzysu pojedynczych instytucji finansowych, które podważają zaufanie (charakter mikroostrożnościowy). Trzecią przyczyną jest kryzys makroekonomiczny, skutkujący masową paniką i efektem zarażania (Dec, Masiukiewicz, 2015). W tym przypadku skala runu na banki przybiera charakter ryzyka systemowego. Obok behawioralnych aspektów paniki bankowej warto zwrócić uwagę na instytucjonalne uwarunkowania systemu finansowego. Zasadą działania banków jest gromadzenie depozytów i udzielanie na tej podstawie kredytów (tak zwany system rezerwy cząstkowej) (Soto, Łuczkiewicz, Machaj, 2011). W związku z tym banki nie przechowują stu procent depozytów ludności. Bezpieczeństwo depozytów opiera się więc na odpowiednim zarządzaniu ryzykiem bankowym (w tym głównie ryzykiem płynności).

\section{Metodologia badań}

Metodę badawczą oparto na wywiadach przeprowadzonych metodą CATI na przełomie października i listopada 2018 roku w próbie 200 osób. Wywiady były skierowane do dorosłych obywateli Polski, z niewielką przewagą kobiet w próbie (K) oraz w równym stopniu osób zamieszkujących na wsi i w miastach (W). Miasta zostały podzielone ze względu na liczbę mieszkańców: do 50 tysięcy $(\mathrm{C} 1), 50$ 100 tysięcy (C2), 100-500 tysięcy (C3) i powyżej 500 tysięcy (C4). Osoby biorące udział w badaniu zostały także zróżnicowane pod względem wykształcenia — podstawowe (P), zawodowe (Z), średnie (Ś) i wyższe. Osoby o wyższym wykształceniu podzielono na dwie podgrupy - z wykształceniem ekonomicznym (WE) i innym (WI). W tabeli 1 przedstawiono liczebności danej cechy respondenta. Dodatkowo sprawdzono ubankowienie ${ }^{3}$ każdej grupy.

Kwestionariusz ankiety został podzielony na dwie części. Pierwsza zawiera dziesięć pytań weryfikujących wiedzę o systemie gwarantowania depozytów w Polsce. Druga część sprawdzała, czy respondent jest skłonny do runu na banki w określonych sytuacjach. Ponadto w kwestionariuszu ankiety umieszczono pytania wskazujące, czy respondenci widzą potrzebę większej edukacji finansowej.

Pytania w kwestionariuszu miały formę testu i dotyczyły różnych obszarów, to jest samego funduszu gwarancyjnego (na przykład „W Polsce istnieje system ochrony deponentów. Za jego prowadzenie odpowiada?"), zasad gwarantowania depozytów (na przykład „Wysokość gwarancji depozytów w Polsce wynosi?”) oraz inne pytania pośrednio związane z DGS (na przykład „Czy w Polsce od początku 2017 roku doszło do upadłości banku?”). W załączniku 1 zamieszczono pytania zadane $\mathrm{w}$ ankiecie oraz odsetek poprawnych odpowiedzi.

${ }^{3}$ Ubankowienie rozumiane jako posiadanie przez obywatela konta w banku lub SKOK. 
Tabela 1. Liczba osób w ankiecie $\mathrm{z}$ daną cechą

\begin{tabular}{|l|c|c|c|c|c|c|c|c|c|c|c|}
\hline \multirow{2}{*}{ Cecha } & \multicolumn{4}{|c|}{ Wykształcenie } & \multicolumn{3}{c|}{ Płeć } & \multicolumn{5}{c|}{ Wiek } \\
\cline { 2 - 13 } & $\mathrm{P}$ & $\mathrm{Z}$ & $\mathrm{S}$ & WE & WI & K & M & $<25$ & $26-45$ & $46-60$ & $<60$ \\
\hline Liczebność & 24 & 42 & 67 & 19 & 48 & 108 & 92 & 22 & 75 & 49 & 54 \\
\hline $\begin{array}{l}\text { Ubankowienie } \\
\text { (w \%) }\end{array}$ & 92 & 88 & 87 & 100 & 94 & 91 & 90 & 95 & 100 & 94 & 72 \\
\hline
\end{tabular}

\begin{tabular}{|l|c|c|c|c|c|}
\hline \multirow{2}{*}{\multicolumn{1}{|c|}{ Cecha }} & \multicolumn{5}{|c|}{ Zamieszkanie } \\
\cline { 2 - 6 } & $\mathrm{W}$ & $\mathrm{C} 1$ & $\mathrm{C} 2$ & $\mathrm{C} 3$ & $\mathrm{C} 4$ \\
\hline Liczebność & 100 & 28 & 14 & 32 & 26 \\
\hline $\begin{array}{l}\text { Ubankowienie } \\
(\mathrm{w} \%)\end{array}$ & 92 & 79 & 93 & 94 & 92 \\
\hline
\end{tabular}

Źródło: opracowanie własne na podstawie wyników CATI.

Pytania weryfikujące skłonność respondenta do runu na banki odnosiły się do różnych sytuacji. Sprawdzały, czy klient jest skłonny do runu w zależności od wielkości banku, który ma kłopoty z terminowym regulowaniem zobowiązań, oraz w zależności od wielkości utrzymywanych w banku środków. Różne sytuacje opisane w pytaniach pomogły między innymi ustalić, czy klienci banku mają świadomość, że system gwarantowania depozytów nie jest gotowy na upadek banku o znaczeniu systemowym (głównie ze względu na spowodowany tym efekt zarażania).

Na końcu kwestionariusza ankiety spytano respondenta, czy jest za wprowadzeniem egzaminu maturalnego z przedmiotu ekonomicznego. Odpowiedzi na to pytanie pozwoliły sprawdzić, czy zauważalna jest potrzeba większej edukacji finansowej wśród respondentów.

Ponadto, na podstawie wyników ankiety skonstruowano model logitowy, w którym zmienną objaśnianą jest zmienna binarna określająca, czy respondent wycofa środki (1) lub nie podejmie żadnej reakcji (0). Zmiennymi objaśniającymi są cechy respondentów (wiek, płeć, miejsce zamieszkania, wykształcenie) oraz wynik z testu wiedzy, która została zweryfikowana poprzez pytania ankietowe.

\section{Analiza wyników badań}

Średni wynik testu wiedzy wyniósł 52\%. Poziom trudności pytań był zróżnicowany — od bardzo prostych, jak ,W Polsce istnieje system ochrony deponentów. Za jego prowadzenie odpowiada?”, po pytania trudniejsze, na przykład „W jakim czasie od spełnienia warunków gwarancji wypłacane są klientom należne środki?". Mimo to jedynie 53\% pytanych wiedziało, że za system gwarantowania depozytów w Polsce odpowiada Bankowy Fundusz Gwarancyjny (BFG). W innym badaniu, przeprowadzonym w 2007 roku, zadano podobne pytanie — „Czy zna 
Pan/Pani Bankowy Fundusz Gwarancyjny?”. Odpowiedź twierdząca pojawiła się jedynie w przypadku 48\% badanych (Stefański, 2007, 25-33). Również w badaniu sfinansowanym przez BFG przeanalizowanym przez Jamrozik-Kierc (2008, 185-180) potwierdzono niską znajomości instytucji gwarantującej depozyty w Polsce. Na wykresie 1 przedstawiono rozkład liczby osób mających określony wynik z testu. Każdego respondenta przypisano do jednej z pięciu grup odpowiadających określonemu poziomowi wiedzy o DGS. Każda z wydzielonych kategorii osób odpowiedna kolejnemu 20. centylowi rozkładu wyników. W załączniku 2 przedstawiliśmy natomiast odsetek prawidłowych odpowiedzi w zależności od danej cechy respondenta.

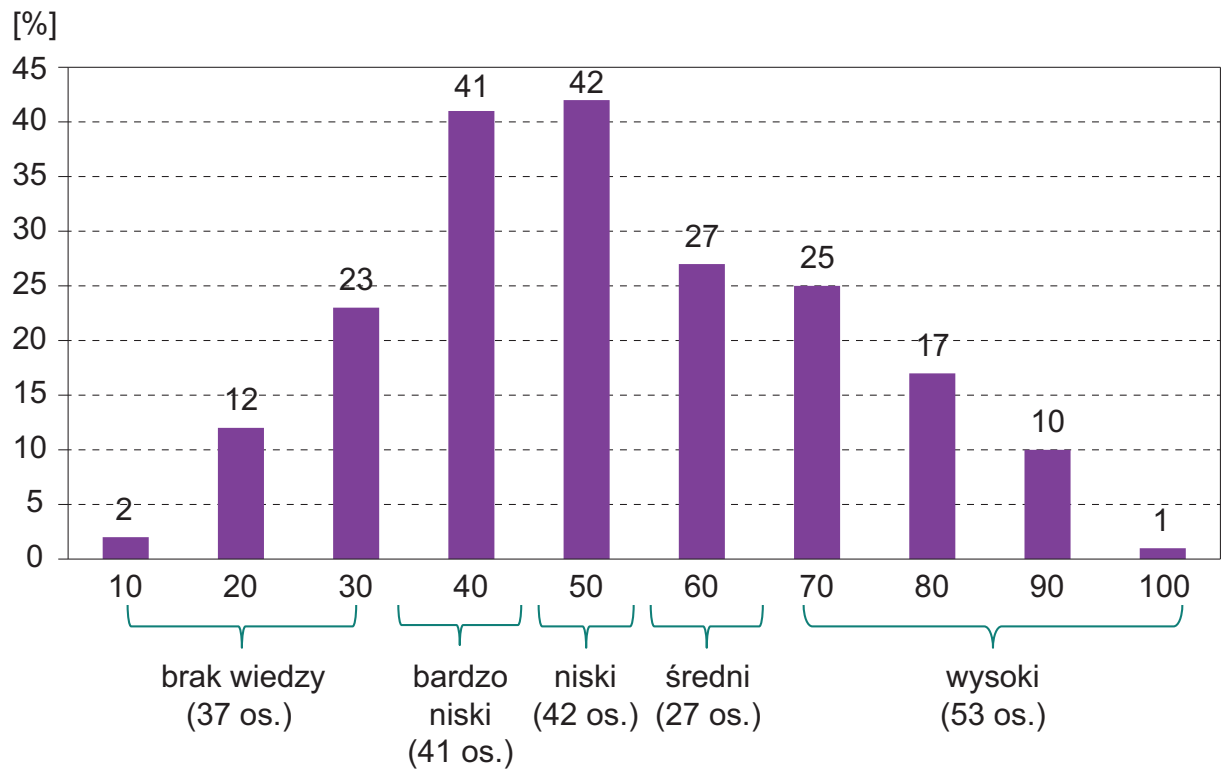

Wykres 1. Rozkład wyników testu

Uwaga: każda z pięciu wydzielonych kategorii odpowiedna kolejnemu 20. centylowi rozkładu wyników. Przykładowo, pierwsza kategoria zawiera osoby niemające wiedzy o DGS i znajdują się w niej respondenci, którzy otrzymali wynik mieszczący się w 20. centylu rozkładu wyników (to jest $10 \%, 20 \%$ oraz $30 \%$ prawidłowych odpowiedzi). Kolejna kategoria to osoby z bardzo niską wiedzą, które odpowiedziały prawidłowo na 4 z 10 pytań, co odpowiada przedziałowi od 20. do 40. centyla rozkładu wyników. Kolejne kategorie ustalono analogicznie do poprzednich.

Źródło: opracowanie własne.

Na podstawie wyników poziom wiedzy każdego z respondentów o DGS przyporządkowano do pięciu kategorii (osoby z brakiem wiedzy, bardzo niską, niską, średnią i wysoką wiedzą). Następnie powiązano poszczególne kategorie z decyzją o wycofaniu środków z depozytu w gotówce (wykres 2), przeniesieniu środków do innego banku (wykres 3) bądź braku reakcji w przypadku pojawienia się 
informacji o problemach z wypłatą środków przez bank, w którym respondent utrzymuje środki.

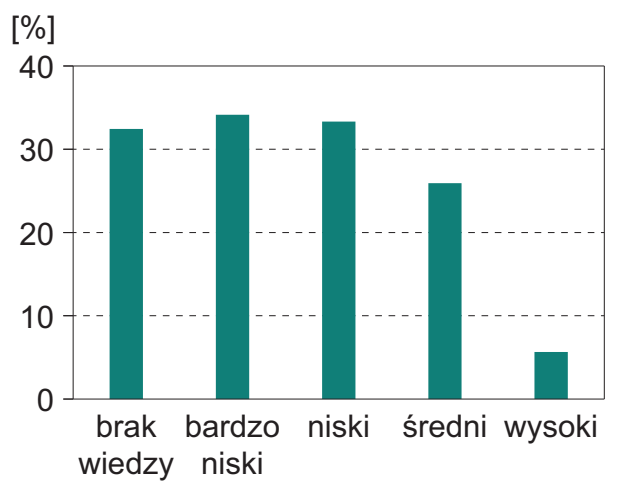

Wykres 2. Odsetek osób, które decydują się na wycofanie środków w gotówce

Źródło: opracowanie własne na podstawie wywiadów CATI.

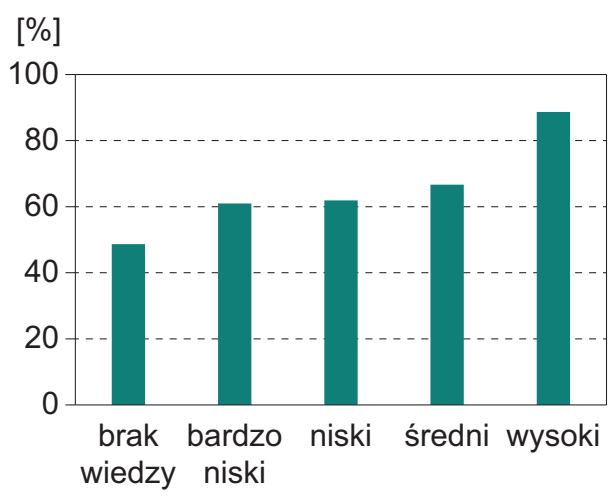

Wykres 3. Odsetek osób, które decydują się na przeniesienie środków do innego banku

Źródło: opracowanie własne na podstawie wywiadów CATI.

Zgodnie z powyższymi wykresami osoby, które otrzymały słaby wynik z testu wiedzy, są bardziej skłonne do wycofywania środków z banku w gotówce. Gotówkowa forma runu jest szczególnie niebezpieczna dla systemu bankowego, gdyż w tym przypadku wycofane środki zmniejszają płynność całego sektora bankowego. W sytuacji, gdy środki pozostają w systemie bankowym, istnieje możliwość łatwego i po względnie niskich kosztach pożyczania środków na rynku międzybankowym od podmiotów, do których trafiły wycofane wcześniej środki. Ponad 30\% osób, które odpowiedziały prawidłowo na mniej niż sześć pytań, było skłonnych do runu gotówkowego. W przypadku osób z wysokim wynikiem z testu wiedzy (wynik powyżej $60 \%$ ) jedynie $6 \%$ było skłonnych do tego typu runu (tabela 2). Jednakże osoby te chętniej przenosiły środki do innego banku, mimo świadomości gwarancji depozytów do określonej kwoty. Wynik testu wydaje się najbardziej decydujący w kwestii skłonności do gotówkowego runu na banki. Pozostałe cechy respondentów, takie jak wiek, płeć, miejsce zamieszkania czy wykształcenie, w mniejszym stopniu różnicują respondentów pod względem decyzji o dokonaniu runu. Wniosek ten jest potwierdzony przez porównywalny udział respondentów skłonnych do runu gotówkowego w danej kategorii pomiędzy zmiennymi charakteryzującymi respondentów (tabela 2). Mimo że różnicowanie grup osób dokonujących runu gotówkowego lub nie w najbardziej istotny sposób dotyczy wyniku testu, to jednak należy zwrócić uwagę na niektóre cechy respondentów sprzyjające decyzji o runie gotówkowym. Patrząc na wyniki ankiety, osoba, która wycofuje środki w gotówce, to najprawdopodobniej kobieta do 25 lat z wykształceniem średnim, mieszkająca w mieście, mająca niewielką wiedzę o systemie gwarantowania depozytów. 
Tabela 2. Skłonność do runu gotówkowego w podziale na cechy respondentów

\begin{tabular}{|c|c|c|}
\hline \multicolumn{2}{|r|}{ Kategoria } & $\begin{array}{l}\text { Udział respondentów skłonnych do runu } \\
\text { gotówkowego w danej kategorii (w \%) }\end{array}$ \\
\hline \multirow{2}{*}{ Płeć } & kobiety & 26 \\
\hline & mężczyźni & 24 \\
\hline \multirow{2}{*}{$\begin{array}{l}\text { Miejsce } \\
\text { zamieszkania }\end{array}$} & miasto & 28 \\
\hline & wieś & 22 \\
\hline \multirow{3}{*}{$\begin{array}{l}\text { Wykształ- } \\
\text { cenie }\end{array}$} & podstawowe i zasadnicze zawodowe & 24 \\
\hline & średnie & 31 \\
\hline & wyższe & 19 \\
\hline \multirow{4}{*}{ Wiek } & do 25 lat & 36 \\
\hline & od 26 do 45 lat & 28 \\
\hline & od 46 do 60 lat & 18 \\
\hline & powyżej 60 lat & 22 \\
\hline \multirow{5}{*}{ Wynik testu } & do 3 poprawnych odpowiedzi & 32 \\
\hline & 4 poprawne odpowiedzi & 34 \\
\hline & 5 poprawnych odpowiedzi & 33 \\
\hline & 6 poprawnych odpowiedzi & 26 \\
\hline & powyżej 6 poprawnych odpowiedzi & 6 \\
\hline
\end{tabular}

Źródło: opracowanie własne na podstawie wywiadów CATI.

Potwierdzeniem wskazanych wniosków są wyniki regresji logistycznej (tabela 3). Istotność cech respondentów przy zmiennej objaśnianej run na banki, ogranicza się w większości do wyniku testu. Interpretując iloraz szans przy zmiennej „wynik testu” należy wskazać, że każdy dodatkowy punkt w teście wiedzy zmniejsza szansę gotówkowego runu na banki o około $25 \%$. Przeciwna zależność zauważalna jest w wypadku runu polegającego na przeniesieniu środków do innego banku. W tej sytuacji im wyższy wynik testu (większa wiedza o systemie gwarantowania depozytów), tym większa szansa na run w formie przeniesienia środków do innego banku. Tym samym główny wniosek, który można wyciągnąć z badania, to: wiedza o systemie gwarantowania depozy tów w istotny sposób determinuje rodzaj runu na banki. Osoby z większą wiedzą o zasadach gwarancji depozytów wybierają mniej niebezpieczną formę runu (czyli przeniesienie środków do innego banku). Osoby z niskim poziomem wiedzy o zasadach gwarancji są bardziej skłonne do runu gotówkowego, co zwiększa medialność paniki bankowej i stwarza zagrożenie dla stabilności finansowej. Jedną z przyczyn takiego zachowania wśród klientów może być powiązanie poziomu wiedzy z majątkiem klienta. Zazwyczaj osoby o większej wiedzy są też bardziej majętne i mogą posiadać kilka kont bankowych jednocześnie. Łatwiej jest im zatem przerzucać środki pomiędzy różnymi kontami. 
Tabela 3. Skłonność do określonego rodzaju runu na banki w zależności od konkretnych cech respondenta

\begin{tabular}{|c|c|c|c|c|c|}
\hline $\begin{array}{c}\text { Zmienna } \\
\text { odniesienia }\end{array}$ & Zmienna & $\begin{array}{l}\text { Run gotów- } \\
\text { kowy (1) }\end{array}$ & $\begin{array}{l}\text { Przeniesie- } \\
\text { nie środków } \\
\text { do innego } \\
\text { banku (2) }\end{array}$ & $\begin{array}{c}\text { Run na } \\
\text { duży bank } \\
\text { (3) }\end{array}$ & $\begin{array}{l}\text { Run przy depo- } \\
\text { zycie równym } \\
\text { dwukrotności } \\
\text { dochodów (4) }\end{array}$ \\
\hline Płeć & kobieta & $\begin{array}{c}1,03 \\
(0,933)\end{array}$ & $\begin{array}{c}1,14 \\
(0,691)\end{array}$ & $\begin{array}{c}1,02 \\
(0,943)\end{array}$ & $\begin{array}{c}1,20 \\
(0,752)\end{array}$ \\
\hline \multirow{3}{*}{$\begin{array}{l}\text { Wiek } \\
\text { powyżej } 60 \\
\text { lat }\end{array}$} & do 25 lat & $\begin{array}{c}1,44 \\
(0,574)\end{array}$ & $\begin{array}{c}0,90 \\
(0,870)\end{array}$ & $\begin{array}{c}0,86 \\
(0,852)\end{array}$ & $\begin{array}{c}4,34 \\
(0,678)\end{array}$ \\
\hline & od 26 do 45 & $\begin{array}{c}1,58 \\
(0,361)\end{array}$ & $\begin{array}{c}0,91 \\
(0,840)\end{array}$ & $\begin{array}{c}1,22 \\
(0,707)\end{array}$ & $\begin{array}{l}8,11 * * * \\
(0,000)\end{array}$ \\
\hline & od 46 do 60 & $\begin{array}{c}0,74 \\
(0,587)\end{array}$ & $\begin{array}{c}1,26 \\
(0,640)\end{array}$ & $\begin{array}{c}0,58 \\
(0,370)\end{array}$ & $\begin{array}{l}5,28 * * * \\
(0,006)\end{array}$ \\
\hline \multirow{4}{*}{$\begin{array}{l}\text { Wykształce- } \\
\text { nie wyższe } \\
\text { ekonomiczne }\end{array}$} & podstawowe & $\begin{array}{c}1,52 \\
(0,670)\end{array}$ & $\begin{array}{c}0,85 \\
(0,850)\end{array}$ & $\begin{array}{c}1,88 \\
(0,448)\end{array}$ & $\begin{array}{c}0,56 \\
(0,557)\end{array}$ \\
\hline & $\begin{array}{l}\text { zasadnicze } \\
\text { zawodowe }\end{array}$ & $\begin{array}{c}3,66 \\
(0,135)\end{array}$ & $\begin{array}{c}0,21^{* *} \\
(0,038)\end{array}$ & $\begin{array}{c}0,82 \\
(0,800)\end{array}$ & $\begin{array}{c}1,02 \\
(0,987)\end{array}$ \\
\hline & średnie & $\begin{array}{c}4,31^{*} \\
(0,087) \\
\end{array}$ & $\begin{array}{c}0,28 * \\
(0,082)\end{array}$ & $\begin{array}{c}0,78 \\
(0,742) \\
\end{array}$ & $\begin{array}{c}0,69 \\
(0,680)\end{array}$ \\
\hline & $\begin{array}{l}\text { wyższe nie- } \\
\text { ekonomiczne }\end{array}$ & $\begin{array}{c}3,98 \\
(0,121)\end{array}$ & $\begin{array}{c}0,35 \\
(0,186)\end{array}$ & $\begin{array}{c}1,28 \\
(0,746)\end{array}$ & $\begin{array}{c}0,75 \\
(0,752)\end{array}$ \\
\hline \multirow{4}{*}{$\begin{array}{l}\text { Miejsce } \\
\text { zamieszka- } \\
\text { nia miasto } \\
\text { powyżej } \\
500 \text { tys. }\end{array}$} & wieś & $\begin{array}{c}1,13 \\
(0,830)\end{array}$ & $\begin{array}{c}0,86 \\
(0,775)\end{array}$ & $\begin{array}{r}6,89^{*} \\
(0,072)\end{array}$ & $\begin{array}{c}0,52 \\
(0,431)\end{array}$ \\
\hline & miasto do 50 tys. & $\begin{array}{c}1,28 \\
(0,715)\end{array}$ & $\begin{array}{c}0,72 \\
(0,625)\end{array}$ & $\begin{array}{c}3,02 \\
(0,364)\end{array}$ & $\begin{array}{c}0,30 \\
(0,222)\end{array}$ \\
\hline & $\begin{array}{l}\text { miasto od } 50 \text { tys. } \\
\text { do } 100 \text { tys. }\end{array}$ & $\begin{array}{c}2,77 \\
(0,187) \\
\end{array}$ & $\begin{array}{c}0,24^{*} \\
(0,067) \\
\end{array}$ & $\begin{array}{l}11,92 * * \\
(0,043)\end{array}$ & $\begin{array}{c}0,29 \\
(0,236)\end{array}$ \\
\hline & $\begin{array}{l}\text { miasto od } 100 \text { tys. } \\
\text { do } 500 \text { tys. }\end{array}$ & $\begin{array}{c}0,75 \\
(0,675)\end{array}$ & $\begin{array}{c}1,03 \\
(0,965)\end{array}$ & $\begin{array}{r}7,17^{*} \\
(0,078)\end{array}$ & $\begin{array}{c}0,65 \\
(0,649)\end{array}$ \\
\hline \multicolumn{2}{|l|}{ Ubankowienie } & $\begin{array}{c}0,76 \\
(0,657)\end{array}$ & $\begin{array}{c}0,65 \\
(0,487)\end{array}$ & $\begin{array}{c}0,37 \\
(0,145)\end{array}$ & $\begin{array}{c}0,08^{* *} \\
(0,027)\end{array}$ \\
\hline \multicolumn{2}{|l|}{ Wynik testu } & $\begin{array}{l}0,74 * * * \\
(0,006)\end{array}$ & $\begin{array}{l}1,39 * * * \\
(0,001)\end{array}$ & $\begin{array}{c}1,13 \\
(0,280)\end{array}$ & $\begin{array}{c}1,13 \\
(0,316)\end{array}$ \\
\hline \multicolumn{2}{|l|}{ Stała } & $\begin{array}{c}0,40 \\
(0,435)\end{array}$ & $\begin{array}{c}1,96 \\
(0,531)\end{array}$ & $\begin{array}{c}0,05^{* *} \\
(0,036)\end{array}$ & $\begin{array}{l}22,87^{*} \\
(0,058)\end{array}$ \\
\hline \multicolumn{2}{|c|}{ Liczba obserwacji } & 200 & 200 & 200 & 200 \\
\hline \multicolumn{2}{|l|}{ Pseudo R2 } & 0,1021 & 0,1216 & 0,0829 & 0,1324 \\
\hline
\end{tabular}

Uwaga: Liczby przedstawione w tabeli są ilorazem szans. W nawiasie pod ilorazem szans znajduje się poziom istotności danej zmiennej. *, **, *** oznaczają p-value, odpowiednio 0,$1 ; 0,05$; 0,01. Poszczególne modele od 1 do 4 dotyczą odpowiednio zmiennej objaśnianej runu gotówkowego (model 1), runu bezgotówkowego (model 2), runu w przypadku dużego banku (model 3) oraz runu w sytuacji poosiadania depozytu w wielkości dwukrotności dochodów (model 4).

Źródło: Opracowanie własne.

Ekonomia. Wroclaw Economic Review 27/1 (2021)

(C) for this edition by CNS 
Dodatkowo sprawdzono, jak zmienia się skłonność do runu na banki w dwóch innych przypadkach. Pod uwagę wzięto wysokość depozytu oraz systemowe znaczenie banku. Oczekiwano, że skłonność do runu będzie zależeć od wielkości utrzymywanych środków oraz rosnąć wraz ze wzrostem znaczenia systemowego banku. Deponenci mogą bardziej obawiać się sytuacji, w której upadek banku może przybrać skalę zagrażającą efektem zarażania. Zgodnie z wynikami deponenci wykazali różną skłonność do runu, jeżeli w pytaniu wskazano wysokość depozytu (w porównaniu do kwoty dochodu). Wykres 4 przedstawia odsetek osób skłonnych do runu gotówkowego w dwóch sytuacjach, to jest bez wskazania w pytaniu wielkości utrzymywanych środków oraz w sytuacji, kiedy ilość środków, utrzymywanych na rachunku bankowym jest równa dwukrotności miesięcznego dochodu respondenta. Podobnie było w przypadku znaczenia systemowego banku. Więcej osób deklarowało chęć wycofania środków w gotówce w przypadku problemów z wypłatą środków przez duży bank działający w kraju (wykres 5). Wydaje się, że respondenci mieli świadomość, iż system gwarantowania depozytów może nie być gotowy na upadek banku o znaczeniu systemowym.

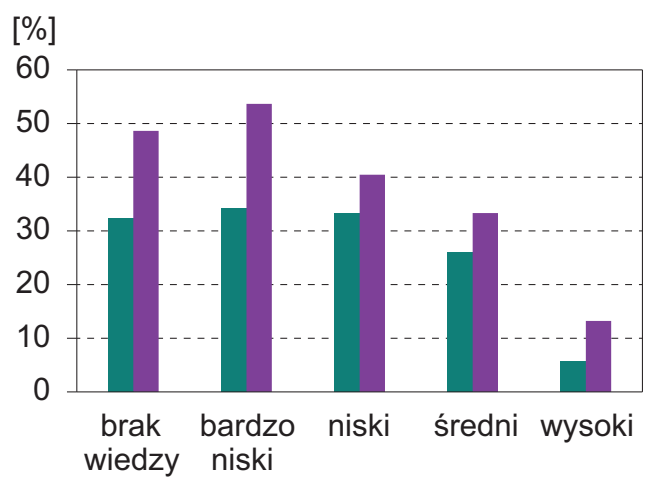

run gotówkowy

run gotówkowy - dwukrotność dochodów

Wykres 4. Wpływ wysokości depozytu na skłonność do runu gotówkowego

Źródło: opracowanie własne na podstawie wywiadów CATI.

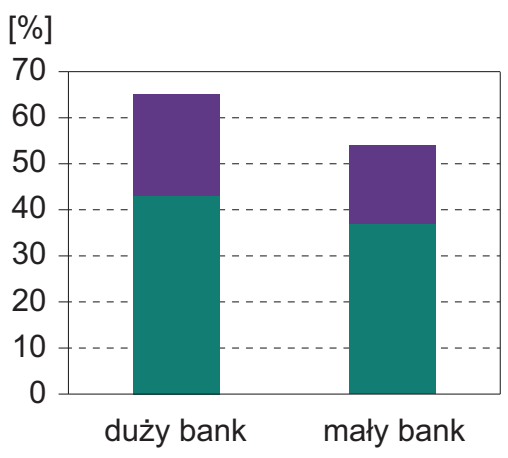

osoby z wynikiem średnim i wysokim osoby z wynikiem niskim, bardzo niskim i brakiem wiedzy

Wykres 5. Udział osób, które decydują się na run gotówkowy w zależności od wielkości banku

Źródło: opracowanie własne na podstawie wywiadów CATI.

Również w tym przypadku sprawdzono (przy użyciu regresji logistycznej) wpływ cech respondenta na decyzję o dokonaniu runu na banki w zależności wielkości banku i kwoty depozytu (tabela 3 - modele 3 oraz 4). Brak istotności zmiennej „wynik testu” potwierdza wcześniej sformułowany wniosek: wiedza o systemie gwarantowania depozytów nie wpływa istotnie na skłonność klientów 
do runu, ale determinuje rodzaj tego runu. W sytuacji runu dokonanego w zależności od wielkości banku oraz kwoty depozytu, znaczenie mają wiek oraz miejsce zamieszkania respondenta. Osoby zamieszkujące na wsi oraz w miastach poniżej 500 tys. mieszkańców wykazują większą skłonność do runu w momencie problemów z regulowaniem zobowiązań przez duży bank. Jeśli natomiast w pytaniu do respondenta dodatkowo wskazano wysokość depozytu równą dwukrotności miesięcznych dochodów, to bardziej skłonne do wycofania środków z banku są osoby od 25 do 60 lat.

Run na banki może być wywołany nieprawdziwą informacją rozprzestrzenioną różnymi kanałami. Dlatego sprawdzono dodatkowo, czy respondenci byliby skłonni do weryfikacji informacji o problemach z wypłatą środków przez ich bank (wykres 6). Okazało się, że prawie 65\% respondentów nie zweryfikowałaby takiej informacji. Pozostałe $35 \%$ respondentów, którzy postanowiliby dokonać weryfikacji, zostało poproszonych o samodzielne wskazanie, gdzie poszukiwaliby wiedzy na ten temat. Odpowiedzi podzielono na cztery najczęściej pojawiające się kategorie oraz ,inne”, do których zaliczono pojedyncze odpowiedzi typu „rodzina”, ,znajomi”, „komisja narodowa” czy „,narodowy fundusz”. Ankietowani wskazywali od jednego do najwyżej trzech miejsc samodzielnego poszukiwania informacji. Najwięcej ankietowanych poszukiwałoby ich w banku, następnie w Internecie. Do kategorii „media” zaliczono radio, telewizję i prasę, wyłączając media internetowe, traktując je jako odrębną kategorię (wykres 7).

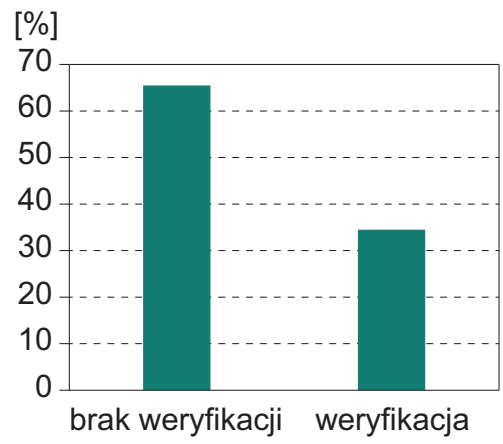

Wykres 6. Udział osób, które zweryfikowałyby informacje o problemach banku z wypłatą środków

Źródło: opracowanie własne na podstawie wywiadów CATI.

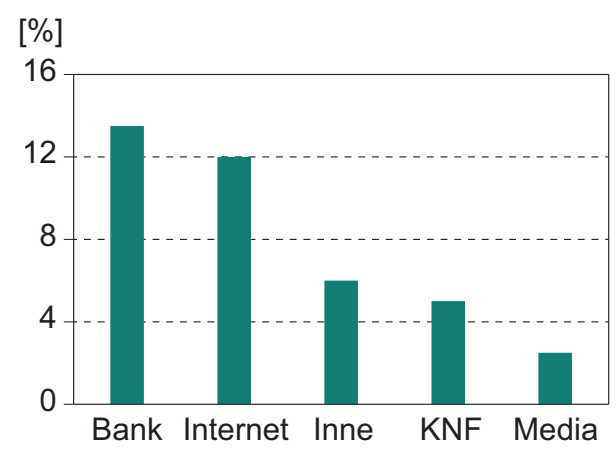

Wykres 7. Udział osób, które wskazały dane źródło informacji o problemach banku

Źródło: opracowanie własne na podstawie wywiadów CATI.

Ponadto postanowiono zweryfikować, czy uczestnicy badania widzą potrzebę większej edukacji finansowej. Dlatego policzono zwolenników wprowadzenia przedmiotu przedsiębiorczość (ekonomia) do grupy przedmiotów maturalnych. Aż $64 \%$ ankietowanych opowiedziało się za takim rozwiązaniem (wykres 8). 


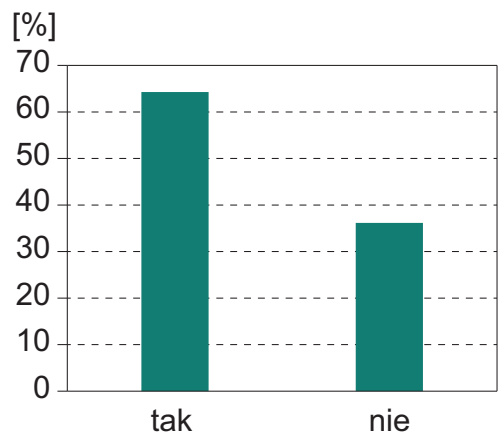

Wykres 8. Udział osób, które są zwolennikami matury z przedsiębiorczości lub ekonomii

Źródło: opracowanie własne na podstawie wywiadów CATI.

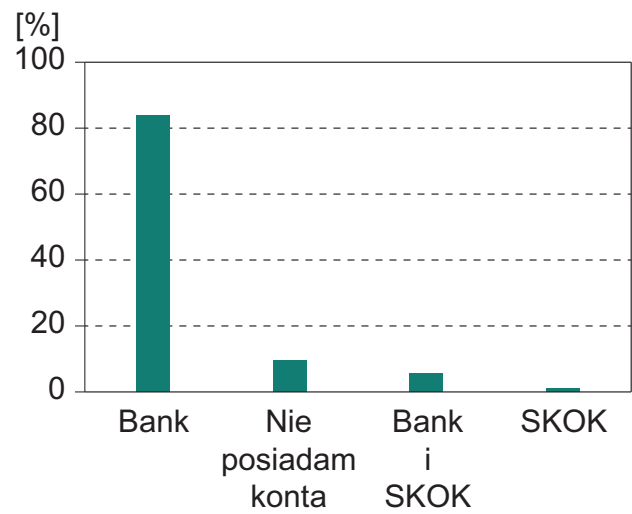

Wykres 9. Udział osób, które posiadają konto w banku, w SKOK-u, banku i w SKOK-u lub nie mają konta

Źródło: opracowanie własne na podstawie wywiadów CATI.

Częstym wyznacznikiem stopnia korzystania z usług finansowych jest poziom ubankowienia, dlatego sprawdzono jego poziom wśród uczestników opisywanego badania. Powszechnie stosowanym miernikiem w tym zakresie jest odsetek osób posiadających konto bankowe (wykres 9). Ponad 90\% ankietowanych posiadało konto w banku lub w SKOK-u. Spośród osób nieubankowionych pięć wskazało, że ich współmieszkaniec posiada konto. Zgodnie z raportem NBP w 2016 roku w Polsce ubankowienie wynosiło 83\% (Maison, 2017), a najbardziej wykluczoną finansowo grupę stanowią osoby powyżej 60. roku życia, co również zostało potwierdzone w niniejszym badaniu. Patrząc na ubankowienie w krajach rozwiniętych, należy wskazać, że zgodnie z danymi Banku Światowego aż 94\% osób w tych krajach posiada konto bankowe.

Uwzględniając niniejszą analizę w polityce stabilności, należy podkreślić, że wzrost poziomu edukacji o systemie gwarantowania depozytów pomoże zwiększyć stabilność systemu finansowego. Wymaga to jednak znacznych nakładów finansowych wspierających programy edukacyjne czy kampanie reklamowe. $\mathrm{W}$ toku analizy wykazano, że respondenci nie są chętni do potwierdzania informacji o problemach danego banku z wypłatą środków ${ }^{4}$. Z tego punktu widzenia ważne jest, aby instytucje sieci bezpieczeństwa finansowego w sytuacji zagrożenia dla stabilności finansowej odpowiednio wcześnie i na szeroką skalę informowały obywateli o istniejących gwarancjach środków utrzymywanych w bankach i in-

${ }^{4} \mathrm{~W}$ ankiecie zadano pytanie: „Czy we własnym zakresie weryfikowałby Pan/Pani informację o problemach z wypłatą środków przez bank, w którym utrzymuje Pan/Pani środki?” Zgodnie z wynikami 131 osób na 200 badanych przyjęłoby taką informację bezkrytycznie. W pozostałych przypadkach respondenci wskazywali, że poszukiwaliby potwierdzenia głównie w KNF, Internecie, NBP oraz na stronach banku. 
nych instytucjach objętych systemem gwarantowania depozytów. Ponadto należy rozważyć rozwiązanie prowadzące do polepszenia edukacji finansowej (w tym edukacji o zasadach gwarancji depozytów) na poziome szkoły średniej. Zdecydowana większość respondentów widzi potrzebę większej edukacji finansowej i jest za możliwością zdawania egzaminu maturalnego z przedmiotu ekonomicznego.

\section{Wnioski}

Obecne tendencje występujące na rynku finansowym, czyli globalizacja, pojawianie się coraz bardziej skomplikowanych usług finansowych oraz zmiany zachodzące w światowej gospodarce (w tym kryzys z 2008 roku), podkreśliły ważną rolę edukacji finansowej. Celem niniejszego artykułu było sprawdzenie kolejnego aspektu, na który może mieć wpływ edukacja finansowa. Jest nim jeden z elementów stabilności systemu finansowego, to jest system gwarantowania depozytów (DGS). W rezultacie postawiono pytanie badawcze: „Czy wiedza o DGS wpływa na skłonność do runu na banki?".

Cel badawczy zrealizowano, przeprowadzając na przełomie października i listopada 2018 roku 200 wywiadów CATI. Zostały one podzielone na dwie części. W pierwszej sprawdzono wiedzę respondentów o systemie gwarantowania depozytów. Część druga zawierała pytania badające zachowania respondentów w określonych sytuacjach. Próba została zróżnicowana pod względem wieku, płci, miejsca zamieszkania oraz wykształcenia. Wyniki wywiadów potwierdziły, że skłonność do runu na banki nie jest istotnie zależna od wiedzy klientów o zasadach gwarancji depozytów. Jednakże wiedza ta w sposób istotny determinuje rodzaj tego runu. Dowiedziono, że osoby z wyższym poziomem wiedzy o DGS były bardziej skłonne do runu bezgotówkowego (to jest przeniesienia środków do innego banku, który nie ma problemów z regulowaniem zobowiązań) niż osoby z niską znajomością zasad gwarancji depozytów. Respondenci z niskim wynikiem z testu wiedzy o DGS byli bardziej skłonni do runu gotówkowego. Potwierdzono również, że respondenci byli bardziej skłonni do wycofania środków z własnego konta w przypadku problemów dużego banku. Skłonność do runu jest mniejsza, jeśli kłopoty z regulowaniem zobowiązań wykazuje mały, lokalnie działający bank. Ponadto osoby, które wzięły udział w badaniu, były niechętne weryfikowaniu informacji o problemach z wypłatą środków przez banki i przyjmowały tę wiadomość bezkrytycznie. Dlatego zarządzając sytuacją kryzysową, instytucje sieci bezpieczeństwa powinny niezwłocznie rozpowszechniać informacje o zasadach gwarantowania depozytów w Polsce.

Wyniki testu wiedzy wykazały, że znajomość zasad gwarancji depozytów w Polsce jest niewielka. Większość pytań nie była trudna i dotyczyły one podstawowych informacji o gwarancji depozytów w Polsce. Jednak jedynie 53\% pytanych wiedziało, że za system gwarantowania depozytów w Polsce odpowiada 
BFG. Średni wynik testu to $52 \%$ i tylko jedna osoba odpowiedziała prawidłowo na wszystkie pytania. Za pozytywny element należy uznać chęć poszerzania wiedzy ekonomicznej wśród respondentów. Większość z nich chciałaby, aby na egzaminie maturalnym wprowadzono możliwość zadawania przedmiotu ekonomicznego.

Definiując kryzysy finansowe, w wielu przypadkach przywoływane są runy na banki oraz panika bankowa. Niektóre przyczyny kryzysu mogą być monitorowane i zarządzane w ramach polityki makroostrożnościowej, na przykład nadmierne zadłużenie czy pokusa nadużycia instytucji finansowych o znaczeniu systemowym. Zarządzanie runem na banki jest trudne i wymaga oddziaływania na nieoczekiwane i spontaniczne działania klientów banków. Na podstawie wyników niniejszej analizy należy wskazać, że jednym z warunków efektywnego działania systemu gwarantowania depozytów jest wiedza obywateli o jego istnieniu i zasadach funkcjonowania. Obok wiedzy obywateli wpływ na efektywność DGS mają również inne czynniki, w tym głównie cechy DGS (między innymi wielkość zgromadzonych funduszy gwarancyjnych), cechy systemu bankowego (na przykład liczba banków o znaczeniu systemowym) oraz poziom zaufania do banków i instytucji sieci bezpieczeństwa finansowego.

\section{Bibliografia}

Banks, J., Oldfield, Z. (2007). Understanding pensions: cognitive function, numerical ability and retirement saving. Fiscal Studies, 28 (2): 143-170.

Campioni, E., Larocca, V., Mirra, L., Panaccione, L. (2017). Financial literacy and bank runs: An experimental analysis. CEIS Research Paper, 402.

Christelis, D., Jappelli, T., Padula, M. (2010). Cognitive abilities and portfolio choice. European Economic Review, 54, 18-38.

Cole, S., Sampson, T., Zia, B. (2011). Prices or knowledge? What drives demand for financial services in emerging markets? The Journal of Finance, 66, 1933-1967.

Diamond, D., Dybvig, P.H. (1989). Bank runs, deposit insurance, and liquidity. The Journal of Political Economy, 91 (3), 401-419.

Dom Badawczy Maison dla Fundacji Kronenberga przy Citi Handlowy. (2009). Stan wiedzy finansowej Polaków - raport z badania ilościowego.

Gorton, G., Metrick, A. (2012). Securitized banking and the run on repo. Journal of Financial Economics, 104 (3), 425-451.

Grinblatt, M., Keloharju, M., Linnainmaa, J. (2009). Do smart investors outperform dumb investors? CRSP Working Paper, 9-33.

Iwanicz-Drozdowska, M. (red.) (2011). Edukacja i świadomość finansowa. Doświadczenia i perspektywy. Warszawa: Oficyna Wydawnicza SGH.

Jamrozik-Kierc, K. (2008). Badanie poziomu wiedzy wśród klientów i pracowników banków na temat systemu gwarantowania depozytów - postrzeganie Bankowego Funduszu Gwarancyjnego w latach 1998-2008. Bezpieczny Bank, 2 (37), 185-180.

Kaufman, G. (1989). Banking risk in historical perspective. Research in Financial Services, 1, 151-164.

Kim, D. (2015). Depositor Runs and Financial Literacy. Working Paper. 
Klapper, L., Lusardi, A., Panos, G. (2012). Financial literacy and the financial crisis. NBER Working Paper, 17930.

Klapper, L., Lusardi, A., Panos, G. (2013). Financial literacy and its consequences: Evidence from Russia during the financial crisis. Journal of Banking \& Finance, 37 (10), 3904-3923.

Komisja Europejska. (2007). Financial Education. Bruksela.

Kurowski, Ł., Laskowska, Z. (2016). Czy edukacja finansowa może zmniejszyć wykluczenie finansowe? E-mentor, 3 (65), 15-23.

Lusardi, A., Mitchell, O. (2014). The economic importance of financial literacy: Theory and evidence. Journal of Economic Literature, 52 (1), 5-44.

Lusardi, A., Tufano, P. (2015). Debt literacy, financial experience, and overindebtedness. Journal of Pension Economics and Finance, 14 (4), 332-368.

Maison, D. (2017). Podstawy Polaków wobec obrotu bezgotówkowego. Raport z badania 2016 $i$ analiza porównawcza z danymi z 2009 i 2013. NBP

Meier, S., Sprenger, C. (2010). Present-biased preferences and credit card borrowing. American Economic Journal: Applied Economics, 2 (1), 193-210.

Narodowy Bank Polski. (2015). Stan wiedzy i świadomości ekonomicznej Polaków.

Narodowy Bank Polski. (2018). Raport o stabilności systemu finansowego — grudzień 2018.

National Audit Office. (2009). The Nationalisation of the Northern Rock. London: HM Treasury.

OECD. (2009). Financial Education And The Crisis. Policy paper and guidance.

Semanova, M. (2017). Bank run in a classroom: Do smart depositors withdraw on time? Higher School of Economics Research Paper, WP BRP 64/FE/2018.

Soto, J.H. de, Łuczkiewicz, G., Machaj, M. (2011). Pieniadz, kredyt bankowy i cykle koniunkturalne. Warszawa: Instytut Ludwiga von Misesa.

Stefański, M. (2008). Klienci banków o systemie gwarantowania depozytów - wyniki badań własnych. Bank i Kredyt, 39 (3), 25-33.

Sundararajan, V., Balino, T.J.T. (1991). Banking Crises: Cases and Issues. Washington, D.C.: International Monetary Fund. 


\section{Załącznik 1. Pytania w ankiecie oraz odsetek poprawnych odpowiedzi}

\begin{tabular}{|l|l|c|}
\hline \multicolumn{1}{|c|}{ Pytanie } & \multicolumn{1}{|c|}{$\begin{array}{c}\text { Prawidłowa } \\
\text { odpowiedź }\end{array}$} & $\begin{array}{c}\text { Odsetek pra- } \\
\text { widłowych } \\
\text { odpowiedzi (\%) }\end{array}$ \\
\hline $\begin{array}{l}\text { W Polsce istnieje system ochrony deponentów. Za jego } \\
\text { prowadzenie odpowiada? }\end{array}$ & BFG & 53 \\
\hline Wysokość gwarancji depozytów w Polsce wynosi? & $\begin{array}{l}\text { równowartość } \\
100 \text { 000 euro }\end{array}$ & 45 \\
\hline $\begin{array}{l}\text { Czy SKOK-i objęte są systemem gwarantowania } \\
\text { depozytów? }\end{array}$ & tak & 60 \\
\hline $\begin{array}{l}\text { Skąd pochodzą środki zgromadzone w funduszu } \\
\text { gwarancyjnym? }\end{array}$ & $\begin{array}{l}\text { składki banków } \\
\text { i SKOK-ów }\end{array}$ & 44 \\
\hline $\begin{array}{l}\text { W jakim czasie od spełnienia warunków gwarancji } \\
\text { wypłacane są klientom należne środki? }\end{array}$ & do 7 dni roboczych \\
\hline $\begin{array}{l}\text { Który organ podejmuje decyzję o zawieszeniu } \\
\text { działalności banku lub SKOK i złożeniu wniosku } \\
\text { o ogłoszenie jego upadłości? }\end{array}$ & $\begin{array}{l}\text { Komisja Nadzoru } \\
\text { Finansowego }\end{array}$ & 20 \\
\hline $\begin{array}{l}\text { Czy w Polsce od początku 2017 roku doszło do } \\
\text { upadłości banku? (na dzień przeprowadzenia badania) }\end{array}$ & nie & 50 \\
\hline $\begin{array}{l}\text { Czy depozyty klientów w walucie obcej są } \\
\text { gwarantowane przez Bankowy Fundusz Gwarancyjny? }\end{array}$ & tak & 52 \\
\hline $\begin{array}{l}\text { Czy każdy bank spółdzielczy zobowiązany jest do } \\
\text { płacenia składek na Bankowy Fundusz Gwarancyjny? }\end{array}$ & tak & $\begin{array}{l}\text { środki finansowe, } \\
\text { gromadzone przez } \\
\text { instytucje paraban- } \\
\text { kowe nie są objęte } \\
\text { gwarancjami }\end{array}$ \\
\hline $\begin{array}{l}\text { Jaką gwarancją są objęte środki finansowe } \\
\text { gromadzone przez instytucje parabankowe? }\end{array}$ & 69 \\
\hline
\end{tabular}

Źródło: opracowanie własne na podstawie wywiadów CATI. 


\section{Załącznik 2. Prawidłowe odpowiedzi w zależności od cechy respondenta}

\begin{tabular}{|l|l|c|}
\hline \multicolumn{2}{|c|}{ Kategoria } & $\begin{array}{c}\text { Odsetek prawidłowych } \\
\text { odpowiedzi (\%) }\end{array}$ \\
\hline \multirow{3}{*}{ Płeć } & kobiety & $51 \%$ \\
\cline { 2 - 3 } & mężczyźni & $49 \%$ \\
\hline \multirow{2}{*}{$\begin{array}{l}\text { Miejsce } \\
\text { zamieszkania }\end{array}$} & miasto & $50 \%$ \\
\cline { 2 - 3 } & wieś & $54 \%$ \\
\hline \multirow{4}{*}{ Wykształcenie } & podstawowe i zasadnicze zawodowe & $49 \%$ \\
\cline { 2 - 3 } & średnie & $50 \%$ \\
\cline { 2 - 3 } & wyższe & $57 \%$ \\
\hline \multirow{4}{*}{ Wiek } & do 25 lat & $38 \%$ \\
\cline { 2 - 3 } & od 26 do 45 lat & $52 \%$ \\
\cline { 2 - 3 } & od 46 do 60 lat & $56 \%$ \\
\cline { 2 - 3 } & powyżej 60 lat & $55 \%$ \\
\hline
\end{tabular}

Źródło: opracowanie własne na podstawie wywiadów CATI. 